\title{
Lateralita, leváctví a specializované funkční oblasti mozku
}

\author{
Ivana Žáková \\ Univerzita Karlova v Praze, Fakulta humanitních studií, Katedra Obecné antropologie, U Kř́že 8, Praha 5 \\ Do redakce doručeno 21. června 2019; k publikaci přijato 13. listopadu 2019
}

\section{LATERALITY, LEFT-HANDEDNESS AND SPECIALIZED FUNCTIONAL AREAS OF THE BRAIN}

\begin{abstract}
The review focuses on the phenomenon of laterality in general and also it focuses on specific forms of laterality that are handedness and the asymmetry of brain hemispheres. The author tries to define the terms, describe the phenomena and explain a potential relationship between the dominant hand and the asymmetry of brain hemispheres, specifically the asymmetry of specialized functional areas in the human brain. There are theories presented in the study that try to answer a question why the laterality of hands and brain evolved. Theories about mechanisms of how laterality can develop at an individual level are presented too, both from genetic and environmental points of view. Study subsequently describes handedness among human population, classification of the laterality of hands and ways how one can tell which hand is the dominant one.
\end{abstract}

KEY WORDS Laterality; handedness; brain hemispheres; brain areas; left handers; right handers

\begin{abstract}
ABSTRAKT Tato přehledová studie se zaměřuje na fenomén laterality obecně i na její konkrétní formy, což jsou leváctví a asymetrie mozkových hemisfér. Autorka se snaží se tyto pojmy definovat, popsat a vysvětlit př́padný vztah mezi vedoucí rukou a asymetrií hemisfér, konkrétně specializovaných funkčních oblastí v mozku člověka. Ve studii jsou nastíněny teorie, které řeší otázku, proč lateralita rukou a mozku evolučně vznikla a z jakých důvodů se vyvine u jedince, a to z hlediska genetických př́čin i možného vlivů prostředí. Studie následně popisuje leváctví a praváctví v lidské populaci, klasifikaci laterality rukou u člověka a možnosti, jak vedoucí ruku určit.
\end{abstract}

KLÍČOVÁ SLOVA Lateralita; leváctví; levorukost; mozkové hemisféry; mozková funkční centra; leváci; praváci

\section{ÚVOD}

Lateralita obecně označuje mj. nerovnoměrné užívání párových orgánů ve smyslu preference či specializace jednoho z nich (tzv. funkční lateralita). U člověka se lateralita může vázat jak k orgánům hybným (horní končetiny), tak i k centrální nervové soustavě (mozkové hemisféry).

Přednostní užívání tzv. vedoucí ruky souvisí se specializací mozkových hemisfér. Levá hemisféra přednostně přijímá informace $\mathrm{z}$ pravé poloviny těla a řídí hybnost pravé poloviny těla. U pravé hemisféry je to přesně naopak. Téměř u $95 \%$ praváků se $\mathrm{v}$ levé hemisféře nachází jednak důležitá centra pro schopnost řeči a jazyku, jednak se zde aktivují oblasti pro gestikulaci. U leváků se ve vyrovnaném zastoupení může objevovat jak uvedená distribuce funkčních center, tak zrcadlově převrácená i symetrická.
V tomto článku se pokusím shrnout základní poznatky o jevech jako je asymetrie obecně a dále levorukost a asymetrie mozkových hemisfér. Tyto informace jsou důležité pro pochopení vzájemných vztahů těchto fenoménů a možných příčin leváctví at už z evolučního hlediska či ontogenetické příčiny leváctví a laterality obecně.

\section{BILATERÁLNÍ ASYMETRIE}

Symetrie, česky též souměrnost, je výraz označujícím rovnost či stejnost určitých objektů ve vztahu k určitému bodu, linii či ploše. Záměna takových objektů by nevyvolala žádné změny celku. Opakem symetrie je asymetrie, česky též nesouměrnost (Clapham - Nicholson 2014; Stevenson 2010).

Většina organismů včetně člověka spadá do živočišného kme- 
ne bilateralia, vyvíjejí se podle tzv. mediolaterální osy a je pro ně charakteristická dvoustranná zrcadlová, tedy bilaterální, souměrnost. Ta je pro ně evolučně adaptivní, protože jejich pohyb je efektivnější než pohyb obloukový. Na druhou stranu se tyto organismy vyznačují i pravolevou nesouměrností, například co se týče distribuce vnitřních orgánů (Koukolík 2012). Lidské tělo se na první pohled vyznačuje výraznou bilaterální symetrií, avšak při detailním zkoumání pozorovatel zjistí tvarové odlišnosti (Synek 1991).

\section{LATERALITA}

Pojem lateralita má původ v latinském slově lateralis, které v češtině znamená boční, postranní. Do češtiny by se tento pojem dal přeložit kostrbatým slovem ,strannovost', který se běžně nepoužívá.

Již samotných definic laterality je více a lze je najít ve dvou základních podobách. V té první je lateralita definována jako jakákoli nesouměrnost mezi levou a pravou stranou ve vztahu $\mathrm{k}$ organismu. Za lateralitu morfologickou bych však neoznačovala jakékoli tvarové odchylky mezi levou a pravou stranou, ale například asymetrickou distribuci orgánů mezi levou a pravou polovinou těla organismu. Druhá definice laterality označuje lateralitu jako nerovnoměrné využívání párových orgánů na základě rozdílů v jejich aktivitě, výkonnosti nebo specializaci. Myslím však, že je nepřesné tvrdit, že jde o rozdíly ve smyslu nadřazenosti jednoho orgánu nad druhým, spíše bych hovořila o preferenci a specializaci jednoho $\mathrm{z}$ párových orgánů k určité činnosti. Takový orgán je možné nazývat jako orgán vedoucí.

Pojem lateralizace pak značí přesun ke straně (Vokurka 2015). Tzn. umístění nějaké struktury na levou či pravou stranu. Speciálním př́ípadem je lateralizované chování, které nevyplývá ze specializace párových orgánů, ale $\mathrm{z}$ nesouměrné distribuce orgánu do jedné poloviny těla; např́klad způsob držení matky jejího novorozence. V roce 1960 začal americký psycholog Salk (1973) pracovat na výzkumu založeném na pozorování matek s dětmi v porodnici. Výzkum vedl ke zjištění, že $80 \%$ matek mělo tendenci brát podvědomě své dítě do levé ruky, a to bez ohledu na to, jestli byly levačky nebo pravačky, tak aby novorozenci slyšeli tlukot matčina srdce. Stejně tak se chovají i primáti. Pokud samice rhesuse potřebuje vzít do jedné paže svého potomka, použije na tento úkon skoro výhradně svou levou paži. Stejně tak činí zhruba $85 \%$ šimpanzů, $82 \%$ goril a $75 \%$ orangutanů (Damerose - Vauclair 2002).

\section{LATERALITA MOZKOVÝCH HEMISFÉR}

Mozek člověka je asymetrický morfologicky, biochemicky i funkčně. Mezi geny a výsledným fenotypem je řada mezičlánků. Funkce jednotlivých proteinů může být jiná, molekulární stavby mohou způsobovat odlišnosti ve strukturách a funkcích neuronů a ty zase ovlivnit stavbu celých neurálních sítí za přičinění vnějších vlivů. (Koukolík 2012). Z určité per- spektivy se dá mozek vnímat jako jediný integrovaný celek. Hranice mezi jednotlivými strukturami jsou většinou neostré a žádná z nich není samostatným prvkem. Z jiné perspektivy se dá mozek, resp. jeho nejobjemnější část - mozek koncový, vnímat jako párový orgán, skládající se ze dvou asymetrických hemisfér, které jsou od sebe odděleny štěrbinou. (Orel 2009). Bílá hmota koncového mozku je složena z nervových vláken, která propojují jednotlivé části mozku. Projekční vlákna propojují mozkovou kůru s dalšími částmi mozku a páteřní míchou. Asociační vlákna spojují korové oblasti ve stejnostranné hemisféře. Naopak komisurální vlákna propojují hemisféry mezi sebou. Tzv. homotopní komisurální vlákna spojují symetrické oblasti v hemisférách, tzv. heterotopní komisurální vlákna spojují asymetrické korové oblasti. Nejmohutnější komisurou je corpus callosum (Orel 2009). Corpus callosum je tuhý svazek nervových vláken, který informace přijaté jednou hemisférou přenáší do druhé (Sternberg 2009).

Šedá hmota je složena $\mathrm{z}$ těl neuronů. Řadí se k ní mozková kůra - hlavní ŕídící vrstva mozku, bazální ganglia a limbický systém (Orel 2009).

V každém laloku se nachází specializované korové oblasti, které mají vymezenou konkrétní funkci. Asociační oblasti, které se zde také nacházejí, jsou spíše integrativního charakteru - jsou to propojené oblasti mozkové kůry, které tvoří anatomický základ pro složité kognitivní činnosti člověka. Asociační oblasti ovlivňují psychické procesy a specifické aspekty lidského chování, emoční proživání a řeč (Orel 2009; Králíček 2011).

Specializované funkční oblasti ${ }^{1}$ spolupracují na zpracování informací s dalšími korovými a podkorovými oblastmi.

V laloku čelním se nachází primární i sekundární (premotorická) motorická kůra. Motoriku také ovlivňuji bazální ganglia, což jsou objemné útvary v šedé hmotě mozkové. V laloku čelním leží Brocovo centrum, které je důležité pro realizaci řeči. Mezi lalokem spánkovým, týlním a temenním leží Wernickeho oblast, která je důležitá zejména pro chápání jazyka (Orel 2009)

$\mathrm{V}$ dnešní době je velmi zavádějící hovořit o jedné hemisféře jako o dominantní. $\mathrm{O}$ asymetrii hemisfér je přesnější mluvit jako o funkční specializaci oblastí v hemisférách. Jedna mozková hemisféra nemá všeobecnou převahu v řízení funkcí, ale je funkčně specializovaná a svou činnost si dělí s opačnou hemisférou za vzájemné spolupráce. Rozdělení na dominantní a nedominantní mozkovou hemisféru mohlo vzniknout $\mathrm{v}$ minulosti např́iklad skrze zjištění, že léze v pravé hemisféře neměly tak závažné důsledky v podobě poruch jako léze v levé hemisféře. Dále to mohlo způsobit právě objevení specializovaných oblastí pro řeč a jazyk v levé hemisfére, což jsou vlastnosti dodnes vnímané jako zásadní a pro člověka jedinečné. Označení levé hemisféry jako dominantní mohlo vzniknout také odvozením $\mathrm{z}$ faktu, že většina lidí používá přednostně pravou ruku, přičemž levá hemisféra přednostně přijímá informace $\mathrm{z}$ pravé poloviny těla a řídí hybnost pravé poloviny těla. U pravé hemisféry je to přesně naopak. Takovému pře-

1 Dále označovány pod zkratkou FO. 
nosu se ř́ká kontralaterální. Pokud jsou přenášeny informace stejnostranně, nazývá se přenos ipsilaterálním. (Sternberg 2009; Pokorná 2010; Kulišsták 2011).

U většiny lidí jsou hemisféry asymetricky uspořádané tak, že v levé hemisfére se nacházejí oblasti specializované oblasti pro řeč a jazyk, zatímco pravá hemisféra zpracovává spíše prostorově-orientační schopnosti a informace s emočním nábojem. Často se však pojem standardní lateralita mozkových hemisfér omezuje na lateralizaci center pro řeč a jazyk, jelikož je to lateralizace nejvýraznější a nejlépe zmapovaná (Ocklenburg a kol. 2014).

Mozek jedince, který je naopak, netypicky lateralizován` se vyznačuje bud' méně výraznou či skoro žádnou ,mezihemisferickou' asymetrií, co se týče distribuce FO (tzv. nevyjádřená lateralizace $\mathrm{FO}$ ), nebo jsou $\mathrm{FO}$ v hemisférách zrcadlově prohozené. Vyskytují se i př́pady, kdy jsou hemisféry typicky asymetrické, co se týče strany, ale funkční oblasti jsou výrazně roztroušeny $\mathrm{v}$ rámci jedné hemisféry, nikoli soustředěné do obvyklého místa. Je pak otázka, kam takový mozek ,zaškatulkovat'.

Starší klasické teorie mluví o preferenci ruky jako o indikátoru lateralizace FO v hemisférách. Tyto dva jevy spolu sice korelují, nicméně dle novějších studií se již ví, že vztah není $100 \%$, obzvlášt u ,nepravákůc. Neurofyziologický základ pro lateralizaci FO nemá stejný základ jako lateralita rukou. Výzkumy naznačují, že by se mohlo jednat o částečnou pleiotropii, nicméně oba jevy jsou ovlivněny dalšími, na sobě nezávislými či málo závislými ontogenetickými faktory, např. působení hormonu testosteron in utero (Ocklenburg a kol. 2014).

Co se týče zastoupení jedinců s typickou a netypickou lateralizací FO v populaci, autoři se shodují na přibližně stejných procentech. Americký kognitivní psycholog Sternberg uvádí, že podle četných výzkumů má 95-99\% praváků typickou lateralizaci FO. Leváci ve zhruba $65 \%$ (2009). Novozélandský psycholog Corballis (2014) uvádí, že praváci mají typickou lateralizaci FO v 96-99\%, ,nepraváci‘ (leváky a ambidextery dále nerozdělil) v $70 \%$, zbylých $30 \%$,nepraváků má hemisféry bud' zrcadlově uspořádány, nebo mají FO rozprostřeny do obou hemisfér. $Z$ českých autorů uvádí pedagožka a psycholožka Pokorná (2010) typickou lateralizaci FO pro jazyk a řeč u praváků v $85 \%$, u leváků v $50 \%$ př́padů a u ambidexterů v $75 \%$, zrcadlově obrácenou uvádí u praváků $10 \%$, u leváků v $35 \%$ a ambidexterů v $13 \%$, symetrickou má $5 \%$ praváků, $17 \%$ leváků a $13 \%$ ambidexterů.

Studie z roku 2000 prováděná pomocí Dopplerovské sonografie $^{2}$ zjištovala aktivitu $\mathrm{v}$ mozkových hemisférách při verbálních úkolech. Účastnilo se jí 330 jedinců v rozmezí 15-50 let (SD: 5), rozdělených na leváky, praváky a ambidextery. Během snímání byla probandům zobrazována písmena a probandi měli následovně vymýšlet (bez hlasité slovní produkce) co nejvíce slov na ně začínajících. Bylo zjištěno, že pravá hemisféra se při těchto úkolech aktivuje u $27 \%$ leváků, $15 \%$ ambidexterů a $4 \%$ praváků (Knecht a kol. 2000).

2 Jedná se o metodu snímání aktivity mozku pomocí ultrazvukových vln měřících rychlost a směr průtoku krve (poznámka autorky).
Kulišták (2011) uvedl, že muži mají v průměru větší velikost mozku, což lze však vysvětlit vyšší průměrnou vahou a výškou mužů. Výsledkem studie zabývající se hustotou neuronů $\mathrm{v}$ mozkové kůře, která byla prováděna $\mathrm{u}$ šesti mužů a pěti žen na 60 místech v mozku, bylo zjištění, že hustota neuronů byla významně větší u mužů. $\mathrm{V}$ jiné studii byl zjištěn vztah mezi zúžením corpus callosum a častějším leváctvím u mužů. Dalším zjištěním bylo, že spánkový lalok v levé hemisfére je u mužů větší (delší), což potvrdilo několik výzkumů. U žen tyto poznatky zjištěny nebyly a také bylo zjištěno, že mužský mozek je uspořádán více asymetricky (Kulišták 2011).

Pacientům s nezvladatelnou epilepsií se ve 20. stol. začal provádět zákrok zvaný kalosotomie, tedy přetětí corpus callosum. Následkem tohoto přetětí bylo jednak znemožnění šíření epilepsie z jedné hemisféry do druhé, ale také tzv. split-brain syndrom, česky syndrom oddělených hemisfér. Otázku funkční specializace hemisfér tak začaly zodpovídat studie právě s těmito pacienty (Koukolík 2012).

\section{EVOLUČNÍ TEORIE O LATERALITĚ}

Začátkem 70. let se vědecká obec domnívala, že lidé se liší od zvírat nejen řečí, ale i lateralitou mozkových hemisfér a leváctvím. Během dekády se skrze různé experimentální studie zjistilo, že hemisféry u zvírat jsou také specializované. Dokonce se levá hemisféra u mnoha druhů aktivuje při učení, gestikulaci či sociální komunikaci, zatímco pravá se aktivuje při zvládání prostorových situací a široké škály citových projevů chování. Lateralita (funkční) tedy není fenoménem unikátním jen pro člověka (Cowell - Denenberg 2002).

Zdá se, že evoluční vývoj laterality by však měl vyústit k výsledku stejnosměrné asymetrie fenotypu živočichů. Pokud by se totiž jedinec s určitou směrovostí jeho chování objevil mezi populací svého druhu, která má směrovost chování opačnou, mohly by nastat četné problémy s intradruhovou interakcí. Stejnosměrná lateralita může být tedy evolučně stabilní strategií (Andrew 2002). Pokud by se ale lidské leváctví aplikovalo např́klad na určitý druh ryby (zjednodušeně řečeno pro demonstraci situace), pak by pro rybu-leváka, která by místo doprava společně se skupinou uhnula před predátorem doleva, toto chování znamenalo jistou smrt. Pokud by se však predátor naučil únikovému manévru jeho kořisti, znamenalo by to pro onoho leváka výhodu, která spočívá v tom, že znemožňuje (predátorům) přizpůsobit se jejich chování vzniklé lateralitou chování. Jde o výhodu frekvenčně závislou (Andrew 2002). Něco podobného může být například výhoda leváků u lidí v nejrůznějších sportech.

Je potřeba rozlišit lateralitu jedince, kdy se v populaci nevyskytuje stejná směrovost, a lateralitu populace, kdy většina jedinců určité populace má stejnosměrnou lateralitu (Rogers 2002). Stejnosměrná lateralita populace může být výhodou tam, kde je potřeba koordinovat chování druhu v rámci nějaké situace, např́íklad plánování útěku či útoku. Lateralitou jedince je např́klad preference jedné končetiny u myši v poměru 50:50. Lateralitou populace je např́íklad preference le- 
vého pařátu u papouška a u člověka pravorukost většiny lidské populace. Individuální lateralita v populaci se stejnou směrovostí může být způsobena například fluktuační asymetrií, třeba $\mathrm{v}$ důsledku činnosti parazita. Pokud je určitá lateralita výhodná pro jedince, nemusí se objevit selekční tlak, aby $\mathrm{v}$ populaci byli všichni lateralizovaní stejnosměrně. Je docela dobře možné, že populace, která zahrnuje leváky i praváky (at' se tím myslí cokoli) těží z kombinace kognitivních a behaviorálních reakcí obou skupin (Rogers 2002).

Lateralita u vyšších obratlovců (ptáci, savci) je s velkou pravděpodobností záležitostí homologie, tedy záležitost zděděná po společném předkovi. Mohla se vyvinout $\mathrm{u}$ druhů nezávisle, ale vzhledem k soudobým poznatkům plynoucích $\mathrm{z}$ fosilních nálezů (fosilní nálezy ukazují na asymetrii v oblasti hlavy i u prvních strunatců) nebo poznatkům o nižších obratlovcích, zejména rybách, u kterých se objevují různé známky laterality, at už funkční či morfologické, se vědci přiklání k první možnosti - tedy k homologii (Vallortigara - Bosazza, 2002).

Lateralita nervového systému předků moderních obratlovců může být například součástí evoluce úspěšného lovu kořisti. Výhody takové laterality jsou pravděpodobně rychlejší reakce a zlepšené projevy chování. Strunatci mají ústní otvor a ústní reflexy potřebné při lovu inervovaný do levé strany mozku, což způsobuje levostranná pozice larvy (Vallortigara - Bosazza 2002). Podobná zjištění jsou i u vyšších obratlovců. Kuřata $\mathrm{s}$ FO pro odpovědi na hrozbu lateralizovanými do pravé hemisféry rychleji detekují predátora. Holubi, kteří mají takto lateralizovaná mozková centra pro zrak, jsou úspěšnější ve vyhledávání potravy (Rogers 2002).

Co se týče preference jedné končetiny u zvírat, tak i zde je možné najít jisté tendence ukazující na výhody takové laterality. Specializace jedné horní končetiny zlepšuje přesnost a rychlost $\mathrm{v}$ různých úkonech. Kočky, které preferují jednu packu (z výzkumů vyplývá, že většinou preferují tu levou), mají rychlejší reakce touto končetinou než ty, které užívají packy stejnoměrně (Rogers 2002). Další výzkum ukázal, že šimpanzi, u kterých lze vypozorovat specializaci horních končetin (jednu končetinu mají specializovanou na držení klacíku a druhou na udržování stability) jsou lepší v lovení termitů než ti, kteří je používají rovnoměrně (McGrew - Marchant 1992). Lateralita mozkových hemisfér má zřejmě ,výpočetní výhody', které s sebou nese právě specializace částí mozku. Další možnou výhodou laterality nervového systému je vyhnutí se zdvojení některých funkcí za účelem ušetření místa. Mozek každého živočicha má omezenou kapacitu pro zpracování a uchování informací, popřípadě schopnost řešit více úkolů naráz. Možnost, jak zvýšit takovou kapacitu je rozdělit úkoly do více regionů (Nowicka - Tacikowski 2011).

\section{LEVÁCTVÍ A PRAVÁCTVÍ U ČLOVĚKA}

Na první pohled nejvíce zřetelnou formou funkční laterality je přednostní uživání jedné či druhé ruky. Kde si anglický jazyk pomůže výrazem handedness, který obecně označuje bud' výraznější zručnost, nebo individuální preferenci k přednost- nímu používání jedné ruky, tam se musí český jazyk uchýlit ke slovnímu spojení „preferování jedné ruky“ nebo ke konkrétnímu označení, zda se jedná o preferenci nebo výraznější zručnost levé ruky či pravé. Tedy výrazům leváctví a praváctví. „Leváctví je prevažující přednostní uživání levých končetin“ (Dvořák 2007). Pokud je potřeba hovořit o preferované ruce obecně, lze použít termín vedoucí ruka.

Je potřeba také podotknout, že leváctví a praváctví nejsou pouze dva dichotomické protipóly (poprr. trichotomie, pokud je zařazena i tzv. ambidextrie), ale kontinuum, ve kterém se nachází více mezistupňů. Existují formy jednoznačně vyhraněné levorukosti a pravorukosti až po formy nevyjádřené (Zelinková 2000; Corballis 2014).

Rozřazení jedinců do skupin podle toho, jakou ruku při činnostech preferují, není zcela jednoduchou záležitostí. V populaci se totiž vyskytují i jedinci, kteří jsou schopni používat obě ruce s víceméně stejnou zdatností, nebo jedinci, kteří užívají jednu ruku pro určitou činnost a druhou ruku pro jinou činnost, a to $\mathrm{v}$ libovolných kombinacích. Kategorizaci mohou navíc ztížit například tzv. přeučení leváci, kteří v naší zemi nejsou stále výjimkami, a také jedinci, kteří jsou naučeni užívat konkrétní ruku pro určitý úkon skrze kulturní tendence, což je ve spoustě společností naprosto běžné. Potíže v rozřazování může způsobit i rozlišení na preferenci jedné ruky a skutečnou zdatnost. Např́íklad měření síly může podle Corballise (1991) vést ke zkresleným výsledkům. Pokud se totiž jedinec od dětství přeučuje na užívání druhé ruky, může tato ruka být následně silnější právě proto, že musela být násilně vytrénována ke zdatnosti.

Pro experimenty jsou jedinci většinou rozřazeni do skupin leváků, praváků a popř. ještě ambidexterů. Skupina ambidexterů většinou zahrnuje jak jedince, kteří jsou schopni stejnoměrně užívat $\mathrm{k}$ činnostem obě ruce, tak $\mathrm{i}$ jedince, kteří pro rozdílné činnosti preferují ruce nerovnoměrně. $\mathrm{V}$ mnoha výzkumech byli ze vzorku ambidextři vyloučeni, nebo byli jedinci rozděleni na praváky a ,nepraváky', kteří zahrnovali všechny ostatní, kromě vyjádřených praváků.

\section{URČENÍ VEDOUCÍ RUKY}

Vesměs všechny metody používané pro určení preferované (vedoucí) ruky jsou založeny na několika spontánně prováděných činnostech, nejlépe každodenních, pro jejichž vykonání se používá jen jedna (ta stejná) ruka.

V zahraničí je nejběžnější dotazník nazývaný Edinburgh Handedness Inventory, zkr. EDI (Oldfield 1971). Zahrnuje deset různých úkonů včetně psaní, kdy dotazovaní jedinci vyplňují, kterou ruku pro jakou činnost používají.

Velmi podobný test pro určení vedoucí ruky jako ten Oldfieldův, byl sestaven britskou psycholožkou Annett, nazýván Annett Hand Preference Questionnaire, zkr. AHPQ. Znovu se jedná o dotazník s otázkami ohledně použití vedoucí ruky v běžných úkonech včetně psaní (Dragovic - Hammond 2007). Annett (1970) ustanovila i praktický test k určení vedoucí ruky zvaný peg-moving task. Úkol spočívá v tom, že jedinci mají 
v co nejrychlejším čase přesunout deset kolíků (po jednom) z otvorů do vzdálenějších otvorů. Ruka, která je rychlejší by měla korelovat s tou, která je vedoucí pro jiné činnosti. Výhodou tohoto testu je, že není ovlivněn zkušenostmi a naučenými činnostmi. Podobný test vymysleli i kanadští psychologové Peters a Durding (1978), kdy je vedoucí ruka určována skrze výkon při tukání ukazováčkem do podložky. U obou těchto testů je výhodou, že je dobře použitelná pro děti. Nedají se s nimi však odhalit ambidextři a další specifické prŕípady.

U nás v roce 1972 ustanovili čeští dětští psychologové Matějček a Žlab tzv. Zkoušku laterality, která má sloužit především $\mathrm{k}$ určení vedoucí ruky u předškolních dětí. Obsahuje deset úkoli̊, které vyžadují užití jedné ruky.

\section{DĚDIČNOST VEDOUCÍ RUKY}

$\mathrm{Z}$ výzkumu, kdy bylo $\mathrm{k}$ určení vedoucí ruky použito úkolu přesouvání kolíků do otvorů (peg-moving task) vyplynulo, že pokud jsou oba rodiče praváky, pak mají v $90 \%$ taktéž pravorukého potomka. Pokud je jeden z rodičů levák, pohybuje se pravděpodobnost, že bude levákem syn okolo $20 \%$ a u dcery okolo $15 \%$. Pokud jsou oba rodiče leváky, pravděpodobnost levorukého syna se zvýší až k 30 \% a u dcery k 20 \% (McManus - Bryden 1991). Výsledky zjištěné v podobném výzkumu, kde však byla určena vedoucí ruka jako ta, kterou jedinec používal ke psaní, přinesly data o několik procent vyšší ve prospěch levorukých potomků. U obou pravorukých rodičů byla $17 \%$ pravděpodobnost, že budou mít levorukého potomka; pokud byl jeden $\mathrm{z}$ rodičů levákem, pak se pravděpodobnost pohybovala od 15 do $25 \%$ (nižší pravděpodobnost byla u dcer). U levorukých rodičů se pravděpodobnost na levorukého potomka vyšplhala až ke 45 \% (Llaurens - Raymond - Faurie 2009).

U monozygotních dvojčat byla ve studii z roku 1999 zjištěna preference opačné ruky zhruba u jedné čtvrtiny (Sicotte - Woods - Mazziotta, 1999).

Preference pro jednu ruku tedy podléhá genetickým vlivům a je do určité míry dědičná. Corballis uvedl, že genetické vlivy vysvětlují jen zhruba čtvrtinu variability, ale jednoduché genetické modely ji nevysvětlují. Dalším problémem mohou být i kulturní vlivy (Llaurens - Raymond - Faurie 2009; Corballis 1991).

V současné době se vědci snaží určit a lokalizovat gen zodpovědný za asymetrii v preferenci jedné ruky. Protože leváctví a ambidextrie zřejmě souvisejí s působením testosteronu in utero, zaměřila se vědecká pozornost na gen kódující činnost transkripčního faktoru pro výrobu receptorů pro androgeny, který je lokalizován na chromozomu X, konkrétně lokusu Xq11.2-q12 (Arning a kol. 2015). Další studie pracovala s faktem, že mezi leváky a ambidextery se vyskytují častěji jedinci s diagnostikovanými neuropsychickými poruchami, jako je např. i schizofrenie. Začala tak probíhat diskuze zaměřující se na gen LRRTM1, který v otcovské linii souvisí se schizofrenií a netypickou lateralizací FO, jejímž projevem je často právě leváctví nebo ambidextrie (Francks a kol. 2007).

Dva nejznámější genetické modely pro vysvětlení preferen- ce jedné ruky jsou od Annett a britského profesora medicíny a psychologie McManuse. Jsou založeny na tom, že určitý gen či geny neurčují, zda bude jedinec levák či pravák, ale spíše určují to, zda bude jedinec mít tendenci k tomu, aby se u něj objevila pravorukost. Tato tendence se označuje jako right-shift, česky možný překlad jako ,přesun dopravá. Pokud jedinec tuto tendenci postrádá, tak to, zda bude levák či pravák bude otázkou náhody. Jinak řečeno, levák je levákem proto, že postrádá gen pro right-shift tendenci (ne proto, že má gen levorukosti). Modely zahrnují i odpovědnost stejného genu (genů) pro rozvoj levé hemisféry jako řečově/jazykově specializovanou (Corbaliss 1991; Annett 2002; McManus 1991).

\section{VLIVY PROSTĽEDÍ NA VEDOUCÍ RUKU}

Genetické př́iciny způsobují preferenci jedné ruky jen z části. Ontogenezi funkční laterality ovlivňuje tedy i vývoj prostředí (Cowell - Denenberg 2002). Co se týče jiných živočichů než člověka, například u kuřat bylo s jistotou zjištěno, že lateralitu mozkových hemisfér u nich způsobuje působení světla během inkubace ve vejci. Změny v hemisféře způsobuje to, které oko je blíže skořápce a vystaveno světlu (Rogers 2002).

První teorie o souvislosti laterality mozkových hemisfér s vlivy prostředí u člověka, kterou v roce 1985 představili američtí neurologové Geschwind a Galaburda, je založena na působení testosteronu in utero, který ovlivňuje vývoj mozkových hemisfér. Vyšší hladina testosteronu má podle této teorie zpomalovat vývoj levé hemisféry. Tato teorie mj. osvětluje souvislost mezi leváctvím či ambidextrií, dyslexií nebo imunologickými poruchami, astmatem a alergiemi. Jedinci s těmito poruchami jsou totiž daleko častěji leváky než praváky. Studie z roku 2003 se potvrdila signifikantně častější výskyt astmatu u ambidexterů a astma s alergickou rýmou u ambidexterů a leváků (Krommydas a kol. 2003). Imunologické změny nastávají zř̀ejmě kvůli hormonálním změnám a mozkové neurochemii, která je způsobena nebo způsobuje pravě lateralitu mozkových hemisfér. U všech těchto poruch je zřejmě společným jmenovatelem právě působení testosteronu in utero (Koukolík 2012). Tuto teorii podporuje i několik studií zaměřujících se na 2D:4D poměr, který je spojován s působením testosteronu in utero, ve vztahu $\mathrm{k}$ levorukosti (Beaton a kol. 2011). V další studii, která tuto teorii podporuje, bylo zjištěno, že lateralita mozkových hemisfér a s tím spojená preference jedné končetiny u zvírat souvisí často s jejich pohlavím, což ukazuje právě na možnost působení pohlavních hormonů in utero jako na příčinu laterality mozkových hemisfér (Cowell - Denenberg 2002).

Jelikož je však hladina testosteronu u těhotných žen vlastností taktéž ovlivněnou geny, je hranice mezi dědičností preference ruky a vlivu prostředí velmi neostrá.

Studie se také zaměřovaly na vztahy mezi porodním traumatem spojeným $s$ hypoxií během porodu, délkou porodu, předčasným porodem, věkem matky nebo nekompatibilním Rh faktorem, společně s později projevenou vedoucí rukou u dětí takto narozených. Zjistil se velký počet levorukých dětí 
s touto anamnézou. Tyto faktory pravděpodobně zasáhnou více levou hemisféru než pravou (Llaurens - Raymond - Faurie 2009).

Jelikož mezi novorozenci s nízkou porodní váhou je velké zastoupení leváků, začalo se pracovat i na výzkumech se snahou ustanovit příčiny tohoto vztahu. Nízká porodní váha je častým důsledkem prenatálních komplikací, které mohou zapříčinit neurologické potíže nebo patologie. Prenatální komplikace mohou znamenat poškození mozku či sama nízká porodní váha může k poškozením mozku vést. Rané poškození mozku pak může způsobit změnu v preferenci jedné ruky (Llaurens Raymond - Faurie 2009).

Rozsáhlá studie z roku 2008 čítala přes 1700 zkoumaných dětí ve věku pěti let, kdy byly zjištovány symptomy $\mathrm{ADHD}^{3}$, řečových poruch a úzkosti u dětí s možnou souvislostí s vedoucí rukou a míry stresu matek těchto dětí během těhotenství. Výsledky daly do souvislostí depresivní sklony ženy během těhotenství či významnou stresovou událost během něj s poruchami řeči, ADHD, úzkostí a ambidextralitou či leváctvím dítěte. U dětí - ambidexterů, byla nalezena souvislost mezi ADHD či poruchou řeči společně s tím, zda matka během těhotenství kouřila. Intepretace ukazují na netypickou lateralitu mozkových hemisfér jako na pojítko mezi ADHD a ambidextralitou (Rodriguez - Waldenström 2008).

\section{TYPY LEVÁCTVÎ/PRAVÁCTVÍ PODLE PŘÍČIN}

Nejčastějším dělením leváctví na různé formy v českých publikacích (i těch současných) je rozdělení na tzv. genotypické a fenotypické leváctví. Genotypická nebo jinak řečeno vrozená levorukost či pravorukost je preference jedné ruky způsobena genotypem jedince. Genotyp = soubor všech dědičných vloh (genů) jedince obsažený v jeho genech nebo dědičná informace pro určitý znak (Vokurka a kol. 2015). Fenotypickým leváctvím/praváctvím je pak to, které se ve skutečnosti projevuje. Fenotyp = „pozorovatelný vzhled či vlastnost jedince, který je výsledkem jeho dědičných vloh (=genotypu) a püsobení prostředi" (Vokurka a kol. 2015). Zde bych však chtěla upozornit na problémovost tohoto rozdělení, pokud nad ním bude uvažováno stále jako v publikaci Sováka (1962), ve které má svůj původ. Tedy v době, kdy se leváctví bralo jako vlastnost plně děděná, kterou je možno měnit až během postnatálního života, a kdy se možné prenatální vlivy, které mohou mít vliv na projevy levorukosti či pravorukosti, nebraly v potaz. Fenotyp byl tedy vnímán pouze jako projev genotypu nebo jako projev jedince, který byl genotypem levák, ale působením pravoruké společnosti nebo přeučením se naučil užívat (a i upřednostňovat) pravou ruku. Tzv. genotypické leváctví či praváctví tedy existuje, ale výsledný projev (fenotyp) může být hormonálními či jinými vlivy změněn ještě v prenatálním období či proděláním porodního traumatu, tedy vlivy vnější-

3 Attention Deficit Hyperactivity Disorder = hyperkinetická porucha (HKP), porucha pozornosti s hyperaktivitou (poznámka autorky). mi. Nakolik se pak takové leváctví či praváctví dá považovat za vrozené či přirozené, jak jej poprvé označil Sovák a po něm další autoři, je otázkou. Existuje i tzv. patologické leváctví či praváctví, kdy je jeho příčinou dysfunkce mozku. Poslední formou, kterou bych zde chtěla zmínit, jsou zvláštní př́ípady, kdy se vrozený levák či pravák během života naučil zručnosti druhé ruky než té, kterou měl původně dominantní, a následně ji při používaní preferoval.

$\mathrm{Z}$ pohledu dnešní vědy bych leváctví či praváctví rozdělila na takové, kdy je příčinou genotyp, dále takové, které je důsledkem vnějších vlivů, at už v prenatální či postnatální fázi života, a na speciální formy leváctví či praváctví, kdy se jedinec naučí používat a nakonec i preferovat druhou ruku. Tzv. patologické formy leváctví jsou takové, kdy je jejich příčinou poškození mozku.

Vzhledem $\mathrm{k}$ soudobým poznatkům o vzniku levorukosti skrze vnější vlivy in utero, které jsem uvedla $\mathrm{v}$ předchozích kapitole, bych však znovu chtěla upozornit na problémovost, co se týče zařazení takové levorukosti do leváctví přirozeného/vrozeného. Myslím totiž, že v mnoha př́padech má blíž spíše k leváctví patologickému. Odpovídají tomu i současné poznatky o vlivech prostředí na vývoj mozku, které vedou $\mathrm{k}$ otázce, jestli jakékoli leváctví či praváctví způsobené vlivy prostředí a nikoli genotypem není patologické. Dalším faktem je, že mezi jedinci s poruchami centrálního nervového systému (patř́ sem epileptici, jedinci se specifickými poruchami učení a další) je skoro dvakrát více leváků než ve zbytku populace. Množí se domněnky, že mezi patologické leváky patří i oni (Delisi a kol. 2002; Llaurens - Raymond - Faurie 2009).

\section{ZASTOUPENÍ LEVÁKŮ V LIDSKÉ POPULACI}

Výsledky studií zjištující poměry leváků ku pravákům v lidské populaci se liší podle toho, jaká činnost se používala $\mathrm{k}$ určení vedoucí ruky a jak se provádění činnosti jednou rukou hodnotilo. Raymond a Pontier (2004) přinesli přehled výsledků 81 studií ze 14 zemí všech kontinentů, kde byla vedoucí ruka určována házením nebo zatloukáním hřebíků. Procentuální zastoupení leváků zjištěno v rozpětí 5-26\%. Perelle a Ehrman (2005), kteří ve své studii zjištovali vedoucí ruku pro psaní, a to na cca 12000 jedincích ze 17 zemí, přinesli výsledek procentuálního rozpětí 2,5-13\%, co se týče zastoupení leváků. Studie v tradičních společnostech (Faurie a kol. 2005) přinesla výsledek relativně velkého rozpětí od 3 do $27 \%$. Ve všech studiích bylo zjištěno nižší zastoupení leváků vůči pravákům, a to $\mathrm{v}$ jakékoli společnosti na světě. Další shodnou tendencí byl větší počet leváků mezi muži než mezi ženami ve většině společností, což podporuje teorii o levorukosti jako o důsledku působení testosteronu in utero. Existují ale i výjimečná zjištění v některých společnostech o vyrovnaném zastoupení žen a mužů mezi leváky a praváky, nebo dokonce výsledky opačné (Llaurens - Raymond - Faurie 2009). McManus (1991) uvadí, že na 10 žen levaček připadá přibližně 13 mužů leváků. Určit poměry leváků ve společnosti je však problematické $\mathrm{z}$ důvodu vícerých forem levorukosti, které jsem zmiňova- 
la výše, dále kvůli existenci také již zmíněných mezistupňů levorukosti podle stupně vyhraněnosti, kdy se při určování vedoucí ruky nemusí dojít $\mathrm{k}$ dichotomickým výsledkům levák/pravák. Český neuropatolog Koukolík (2012) upozorňuje i na nejednoznačnost pojmu leváctví např́č společnostmi, kdy v jedné může být jedna ruka kulturně určená pro vykonávání určité činnosti, zatímco $\mathrm{v}$ jiné společnosti to může být ruka opačná a v jiných společnostech takové činnosti či určení nemusí vůbec dávat smysl.

Studie, ve kterých se autoři zabývali preferencí ruky v době kamenné a bronzové, se shodují na poměru ve výrazný prospěch praváků, podobný tomu současnému. Jde například o studie z let 1997 či 2005, kdy byl tento poměr zkoumán na základě kosterních nálezů (např. délky pažních kostí), kamenných nástrojů a dalších lidských artefaktů (Phillipson 1997; Steele - Uomini 2005).

\section{ZÁVĚR}

Problematika zkoumání leváctví je vědecky a informačně podceněna. $\mathrm{V}$ české literatuře je jen velmi málo kvalitních a aktuálních publikací o tomto fenoménu. Scházejí podrobné a přesné informace, což může jednoduše vést $\mathrm{k}$ nepochopení celé problematiky. Takový přístup je pak nebezpečný zejména proto, že leváctví může souviset s nejrůznějšími poruchami a potížemi různé závažnosti a je třeba pracovat s postiženými jedinci individuálně, nikoli vytvářet stereotypní představy o všech levácích

Pro pochopení je potřeba pokusit se odpovědět na otázky jak a proč lateralita rukou a zraku u člověka evolučně vznikla, jak se vyvíjí u jednotlivce a jak funguje propojení mozku a rukou. Leváctví je jevem, který může být způsoben více příčinami, navíc $\mathrm{v}$ různým kombinacích, a může být ovlivněno ve více fázích života, at’ už prenatálního, či postnatálního. Dále je očividně spojeno s lateralizací specializovaných funkčních oblastí v mozkových hemisférách, ovšem nutno podotknout, že ne tak, jak o tom bylo smýšleno v historii. Vztah mezi lateralitou mozkových hemisfér a vedoucí ruky není zdaleka tak přímočarý, jak se dříve myslelo a složitost tohoto vztahu svým způsobem odpovídá komplikovanosti příčin vzniku leváctví.

\section{LITERATURA}

Andrew, R. J. (2002): The earliest origins and subsequent evolution of lateralization. In: Rogers L. J. - Andrew R. (eds.) Comparative vertebrate lateralization. Cambridge University Press.

Annett, M. (1970): The growth of manual preference and speed. British Journal of Psychology, 61(4), 545-558.

Annett, M. (2002): Handedness and brain asymmetry: The right shift theory. Psychology Press.

Arning, L. a kol. (2015): Handedness and the X chromosome: The role of androgen receptor CAG-repeat length. Scientific Reports, 5, 8325.

Beaton, A. A. a kol. (2011): Digit ratio (2D: 4D), salivary testosterone, and handedness. Laterality, 16(2), 136-155.

Clapham, Ch. - Nicholson, J. (2009): The concise Oxford dictionary of mathematics. Oxford: OUP.
Corballis, M. C. (1991): The lopsided ape: evolution of the generative mind [online]. New York: Oxford University Press. [cit. 2. 3. 2016].

Corballis, M. C. (2014): Left Brain, Right Brain: Facts and Fantasies. PLoS Biology, 12(1), e1001767. Dostupné z: doi:10.1371/journal.pbio.1001767

Cowell, P. E. - Denenberg, V. H. (2002): Development of laterality and the role of the corpus callosum in rodents and humans. In: Rogers L. J. Andrew R. (eds.) Comparative vertebrate lateralization. Cambridge University Press.

Damerose, E. - Vauclair J. (2002): Posture and laterality in human and non-human primates: Asymmetries in maternal handling and the infant's early motor asymmetries. In: Rogers, L. J. - Andrew R. (eds.) Comparative vertebrate lateralization. Cambridge University Press.

Delisi, L. E. a kol. (2002): Hand Preference And Hand Skill In Families With Schizophrenia. Laterality, 7(4), 321-332.

Dvořák, J. (2007): Logopedický slovník: [terminologický a výkladový]. 3. vyd. Ždár nad Sázavou: Logopedické centrum.

Dragovic, M. - Hammond, G. (2007): A classification of handedness using the Annett Hand Preference Questionnaire. British Journal of Psycholo$g y, 98(3), 375-387$.

Faurie, C. a kol. (2005): Variation in the Frequency of Left-handedness in Traditional Societies. Current Anthropology, 46(1), 142-147.

Francks, C. a kol. (2012): LRRTM1 On Chromosome 2P12 Is A Maternally Suppressed Gene That Is Associated Paternally With Handedness And Schizophrenia. Molecular Psychiatry, 12(12), 1129-1139.

Geschwind, N. - Galaburda, A.M. (1985): Cerebral lateralization: Biological mechanisms, associations, and pathology: I. A hypothesis and a program for research. Archives of Neurology, 42(5), 428-459.

Knecht, S.a kol. (2000): Handedness and hemispheric language dominance in healthy humans. Brain, 123(12), 2512-2518.

Koukolík, F. (2012): Lidský mozek: [funkční systémy, norma a poruchy]. 3. vyd. Praha: Galén.

Krommydas, G. a kol. (2003): Left-Handedness In Asthmatic Children. Pediatric Allergy \& Immunology, 14(3), 234-237.

Kulišták P. (2011): Neuropsychologie. 2. vyd. Praha: Portál.

Llaurens, V. - Raymond, M. - Faurie, Ch. (2009): Why are some people left-handed? An evolutionary perspective. Philosophical Transactions of the Royal Society of London B: Biological Sciences, 364(1519), 881-894.

McGrew, W. C. - Marchant, L. F. (1992): Chimpanzees, tools, and termites: Hand preference or handedness? Current Anthropology, 33, 114-119.

McManus, I.C. - Bryden, M.P. (1991): Geschwind's theory of cerebral lateralization: developing a formal, causal model. Psychol. Bull., 110, 237-253.

Nowicka, A. - Tacikowski, P. (2011): Transcallosal Transfer Of Information And Functional Asymmetry Of The Human Brain. Laterality, 16(1), 35-74.

Ocklenburg, S. a kol. (2014): The ontogenesis of language lateralization and its relation to handedness. Neuroscience \& Biobehavioral Reviews, 43, 191-198.

Oldfield, R. C. (1971): The assessment and analysis of handedness: the Edinburgh inventory. Neuropsychologia, 9(1), 97-113.

Orel, M. a kol. (2009): Člověk, jeho mozek a svět. 1. vyd. Praha: Grada

Perelle, I. B. - Ehrman, L. (2005): On the other hand. Behavior genetics, 35(3), 343-350.

Peters, M. - Durding, B. M. (1978): Handedness measured by finger tapping: a continuous variable. Canadian Journal of Psychology/Revue canadienne de psychologie, 32(4), 257.

Phillipson, L. (1997): Edge modification as an indicator of function and handedness of acheulian handaxes from Kariandusi, Kenya. Lithic Technolo$g y, 22(2), 171-183$.

Pokorná, V. (2010): Teorie a náprava vývojových poruch učení a chování. 4. vyd. Praha: Portál.

Raymond, M. - Pontier, D. (2004): Is there geographical variation in human handedness? Laterality: Asymmetries of Body, Brain and Cognition, 9(1), 35-51.

Rodriguez, A. - Waldenström, U. (2008): Fetal Origins Of Child Non-Right-Handedness And Mental Health. Journal Of Child Psychology \& Psychiatry, 49(9), 967-976.

Rogers, L. J. (2002): Advantages and disadvantages of lateralization. In: Rogers, L. J. - Andrew, R. (eds.) Comparative vertebrate lateralization. Cambridge University Press. 
Salk, L. (1973): The role of the heartbeat in the relations between mother and infant. Scientific American, 228(5), 24-29.

Sicotte, N. L. - Woods, R. P. - Mazziott,a J. C (1999): Handedness in twins: a meta-analysis. Laterality: Asymmetries of Body, Brain and Cognition, $4(3), 265-286$.

Sovák, M. (1962): Lateralita jako pedagogický problém. 1. vyd. Praha: SPN.

Sternberg, R. J. (2009): Kognitivní psychologie. 2. vyd. Praha: Portál.

Stevenson, A. (ed). (2010): Oxford dictionary of English. Oxford University Press, USA.

Synek, F. (1991): Záhady levorukosti: asymetrie u člověka. 1. vyd. Praha: Horizont.

Vallortigara, G. - Bisazza, A. (2002): How ancient is the brain lateralization. In: Rogers L. J. - Andrew, R. (eds.) Comparative vertebrate lateralization. Cambridge University Press.

Vokurka, M. a kol. (2015): Praktický slovník medicíny. 11. vyd. Praha: Maxdorf.

Zelinková, O. (2000): Poruchy učení. 5. vyd. Praha: Portál.

Žlab, Z. - Matějček, Z. (1972): Zkouška laterality. Bratislava: Psychodiagnostika.

\section{AUTORKA}

Žáková, Ivana, získala titul Mgr. v magisterském oboru Obecná antropologie na Fakultě humanitních studií na Univerzitě Karlově v Praze a v současné době je studentkou v doktorském studiu Obecná antropologie - Integrální studium člověka. Hlavním zaměřením jejího studia je biologická antropologie a etologie.

Kontakt: Mgr. Ivana Žáková, Univerzita Karlova v Praze, Fakulta humanitních studií, Katedra Obecné antropologie, U Kříže 8, Praha 5 E-mail: itsivanazak@gmail.com 